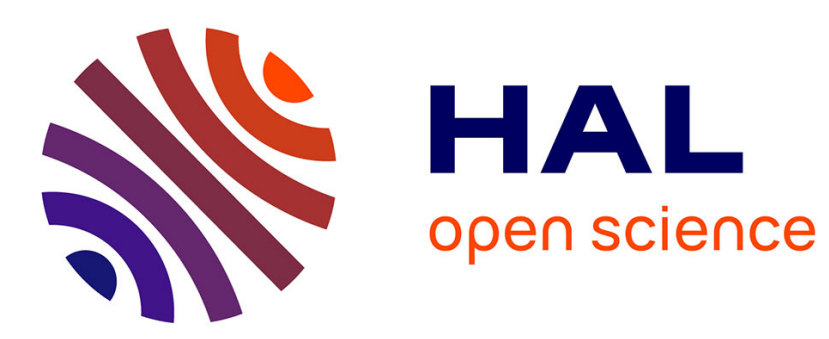

\title{
FSH treatment of male idiopathic infertility: Time for a paradigm change
}

\author{
Manuela Simoni, Daniele Santi
}

\section{To cite this version:}

Manuela Simoni, Daniele Santi. FSH treatment of male idiopathic infertility: Time for a paradigm change. Andrology, In press, 10.1111/andr.12746 . hal-02501219

\section{HAL Id: hal-02501219 \\ https://hal.science/hal-02501219}

Submitted on 6 Mar 2020

HAL is a multi-disciplinary open access archive for the deposit and dissemination of scientific research documents, whether they are published or not. The documents may come from teaching and research institutions in France or abroad, or from public or private research centers.
L'archive ouverte pluridisciplinaire HAL, est destinée au dépôt et à la diffusion de documents scientifiques de niveau recherche, publiés ou non, émanant des établissements d'enseignement et de recherche français ou étrangers, des laboratoires publics ou privés. 


\section{ANDROLOGY}

FSH TREATMENT OF MALE IDIOPATHIC INFERTILITY: TIME FOR A PARADIGM CHANGE

\begin{tabular}{|c|c|}
\hline Journal: & Andrology \\
\hline Manuscript ID & ANDR-2019-0431.R1 \\
\hline Manuscript Type: & Opinion Article \\
\hline $\begin{array}{r}\text { Date Submitted by the } \\
\text { Author: }\end{array}$ & $\mathrm{n} / \mathrm{a}$ \\
\hline Complete List of Authors: & $\begin{array}{l}\text { Simoni, Manuela; University of Modena and Reggio Emilia, Department } \\
\text { of Medicine Endocrinology and Metabolism } \\
\text { Santi, Daniele; University of Modena and Reggio Emilia, Biomedical, } \\
\text { Metabolic and Neural Sciences }\end{array}$ \\
\hline Major Area: & Clinical \\
\hline Clinical: & \\
\hline Basic Science: & \\
\hline Specific Topics: & Gonadotropins and gonadotropins receptors \\
\hline
\end{tabular}


61 Unit of Endocrinology, Department of Biomedical, Metabolic and Neural Sciences, University of

7 Modena and Reggio Emilia, Modena, Italy.

$8{ }^{2}$ Unit of Endocrinology, Department of Medical Specialties, Azienda Ospedaliero-Universitaria of 9 Modena, Modena, Italy

$10{ }^{3}$ BIOS, INRA, CNRS, IFCE, Université de Tours, Nouzilly, France.

11 LE STUDIUM RESEARCH FELLOW, Loire Valley Institute for Advanced Studies, Orléans \& Tours, France 12 


\section{Abstract}

2 Follicle-stimulating hormone (FSH) has been used in inconclusive clinical trials for male idiopathic

3 infertility in the past. FSH is sometimes prescribed empirically for male idiopathic infertility, showing

4 some improvement in sperm parameters in about half of the patients. In this opinion article we

5 briefly analyze the pathophysiological evidences in favor of a more aggressive approach in planning

6 future studies on pharmacological FSH use in male infertility, in analogy with the FSH use for

7 multiple follicular growth in women undergoing ovarian stimulation for assisted reproduction.

8 There is sufficient evidence that spermatogenesis does not run at its top in the primate and that

9 some extra FSH can stimulate spermatogenesis over its baseline. Existing data suggest that the 10 pharmacological regimens applied so far were insufficient, both in dosage and in duration, to elicit 11 this response in about half of the patients. A paradigm change is needed now: we should move away 12 from the classical, endocrinological approach, which simply applied the substitutive, therapeutic 13 regimen used in hypogonadotropic hypogonadism, towards testing a "testicular hyperstimulation" 14 scheme for a time sufficient to cover more than only one spermatogenic cycle, a concept to be 15 verified in an appropriately controlled, prospective, randomized clinical trial.

\section{Introduction}

The problem of male idiopathic infertility is surely well-known to the readership of this

19 journal and does not need to be extensively introduced. Here, we would like to remind only two 20 crucial aspects relevant for this article: i) some sort of male factor is present in about $50 \%$ of cases 21 of couple infertility (Colpi, et al., 2018) and ii) in most of the cases an etiological therapy does not 22 exists and a pregnancy requires assisted reproduction technology (ART). The latter means that it is 23 the woman who has to undergo ovarian stimulation, with its implications and consequences, even 24 if she is perfectly fertile. In this sense, the discovery of intracytoplasmic sperm injection (ICSI), while 
1 crucial to allow paternity, not only was a disaster for research on male infertility but also introduced

2 another burden to women. ART for male infertility is probably the most dramatic example of gender

3 inequity in medicine, along with hormonal contraception.

Couple infertility is a very peculiar field of medicine for several reasons. The causes remain

5 unknown in about one third of the cases (De Jonge and Barratt, 2019); it is not perceived as medical

6 problem worth of thorough research, which means that it remains under-supported by the funding

7 agencies (while animal reproduction, instead, is much more subsidized); treatments are mostly

8 empirical and not evidence-based; the burden of the treatment is carried by the women in most of

9 the cases; the field is dominated by gynecologists, while males are rarely referred to the proper 10 doctor, i.e. the andrologist; treatments are often conducted in private clinics, at the costs of the 11 patients, in most countries of the world.

In this hostile scenario, is there anything that can be done now to improve medical practice in cases of male idiopathic infertility? In this opinion article we would like to analyze the case of follicle-stimulating hormone (FSH) therapy, an option which has been snubbed enough and now needs to be re-evaluated in the light of the most recent evidences. The pharmacological use of FSH for the treatment of male idiopathic infertility needs to undergo a paradigm change.

\section{Targets of FSH action in spermatogenesis}

In humans, FSH stimulates spermatogenesis both independently from testosterone and with 20 a mechanism partially overlapping with testosterone. Spermatogenesis occurs in proliferation and 21 maturation steps, requiring autocrine, paracrine and endocrine stimuli that are guaranteed by both 22 FSH and testosterone (Jan, et al., 2012, Oduwole, et al., 2018). FSH mainly acts in the first stages 23 ("FSH dependent phase" - Figure 1), whereas testosterone works in the last steps (Figure 1). The 24 leading FSH roles on spermatogenesis are: i) determination of Sertoli cells number; ii) 
1 spermatogonial proliferation as well as metabolic and structural support; iii) stimulation of meiotic

2 progression until spermatids stage; iv) metabolism and transport of nutritive substances to germ 3 cells. $7 \quad$ al., 2010).

FSH acts on Sertoli cells, interacting with the FSH receptor (FSHR) (Kangasniemi, et al., 1990).

On the other hand, testosterone comes from the luteinizing hormone (LH) action on Leydig cells, reaching a 50-100-fold higher concentration within testes rather than in blood circulation (Roth, et

FSH determines the final Sertoli cells number during neonatal and peri-pubertal life (Sharpe, et al., 2003), increasing the transcription of Sertoli cell genes involved in DNA replication and cell cycle regulation (Zimmermann, et al., 2015). Although the FSHR is expressed since the second half of gestation, it is the neonatal pituitary FSH onset and its peri-pubertal raise that activate the FSHR (Huhtaniemi, et al., 1987) and stimulate Sertoli cell proliferation (Sharpe, et al., 2003), respectively. In adult life, FSH stimulates Sertoli cells to produce regulatory molecules and nutrients required for germ cells maturation (Cheng and Mruk, 2002), and its circulating levels correlate directly with Sertoli cells number and testicular volume (Allan, et al., 2004).

Recent findings obtained by genetically modified mouse models increased our knowledge about FSH role in spermatogenesis. In adult mouse testis, FSH stimulates Sertoli cells to produce anti-apoptotic survival factors and adhesion molecules, facilitating germ cells maturation until the 19 round spermatids stage (Figure 1) (Ruwanpura, et al., 2010). However, the lack of FSH or FSHR 20 reduces the Sertoli cells number but does not cause sterility (Abel, et al., 2000, Kumar, et al., 1997), 21 suggesting that FSH is not absolutely necessary for spermatogenesis in the mouse. In humans, only 22 one inactivating FSHR mutation was described in five males (Tapanainen, et al., 1997). Despite the 23 receptor defect, these men were subfertile, with normal testosterone levels, reduced 24 spermatogenesis, but not necessarily azoospermia. This result reflects the clinical picture of Fshr- 
1 KO mice models and was interpreted as demonstrating that spermatogenesis may be possible

2 without FSH action, although an alternative explanation was offered recently by a more complete

3 exploration of FSHR signaling (Tranchant, et al., 2011). On the contrary, the only five men described

4 so far with FSHB mutations were all azoospermic (Zheng, et al., 2017), suggesting that

5 spermatogenesis cannot take place without FSH action in man. However, the paucity of human

6 FSHB/FSHR mutations does not allow to fully describe the role and molecular mechanism of FSH in

7 human spermatogenesis.

FSH works in synergy with testosterone, which is imperative for blood-testis barrier

9 development and function, whereas FSH is permissive in the organization of tight junctions and

ectoplasmic specialization (Sluka, et al., 2006, Stanton, 2016, Zimmermann, et al., 2015). In some

circumstances, intratesticular testosterone can compensate for the insufficiency of FSH action (Abel, et al., 2008) . FSH and testosterone stimulate different aspects of spermatogenesis, showing both addictive and synergic pathways (Abel, et al., 2008). Without any doubt, however, qualitatively and quantitatively normal spermatogenesis does not occur in the absence of FSH action.

\section{Is FSH efficacious for treating male idiopathic infertility?}

In male idiopathic infertility, FSH may be empirically used to stimulate residual spermatogenesis and to improve sperm production when FSH serum levels are within the normal range (Barbonetti, et al., 2018, Colpi, et al., 2018). However, the clinical efficacy of FSH remains a matter of debate. Seventeen controlled clinical trials (too few) and four meta-analyses (too many) 21 evaluated so far the efficacy of FSH administration to the male partner of infertile couples. Although 22 meta-analyses are generally useful to achieve an overall view on FSH efficacy, they consider 23 pregnancy rate as primary endpoint, introducing potential biases related to the female partner. 24 Indeed, while an overall pregnancy rate increase was found in couples in which the man was treated 
1 with FSH (Attia, et al., 2013, Attia, et al., 2007, Santi, et al., 2015), the number needed to treat (NNT)

2 was high. From 10 to 18 men should be treated to achieve one pregnancy (Santi, et al., 2015), a

3 number too large to recommend extensive use of FSH.

4

5

Anyhow, some effect is there and the elevated NNT could be due to inadequacy of the current FSH treatment regimen. Indeed, the FSH type, scheme and dosage used in clinical trials were highly heterogeneous (Table 1 ) and no conclusive results have ever been produced about the most effective FSH regimen. Recently, a dose-dependent sperm concentration and total sperm count improvement was described in a meta-analysis, which was, however, based on only three studies and a very limited number of patients (Cannarella, et al., 2019). With these limitations, the higher the FSH dose used, the greater was the increase in sperm production (Cannarella, et al., 2019). Thus, limited evidence suggests that high FSH doses may be useful to stimulate Sertoli cells, providing a stronger support to germ cells proliferation and maturation. Accordingly, when FSH was used at high dosages (300 IU daily) the NNT decreased to 12 and 6 for spontaneous and ART pregnancies, respectively (Ding, et al., 2015). Recently, we performed a nation-wide, clinical practice survey in Italy, showing that FSH administration leads to a significant increase in sperm concentration and morphology, when used at $150 \mathrm{IU}$ on alternate days (Santi, et al., Submitted).

Similarly, to the FSH dose, also the treatment duration is not supported by strong scientific evidence. Spermatogenesis is a long process, requiring 72-90 days for completion. Thus, a prolonged 19 stimulation would be required to increase sperm production. Whether the three months of 20 treatment generally applied (i.e. the time needed to cover at least one spermatogenic cycle) are 21 sufficient to obtain a clinical effect is not clear so far. We recently demonstrated that the sperm 22 quality improvement after FSH administration in male idiopathic infertility is evident only after three 23 months of therapy and continues after further three months of treatment withdrawal (Simoni, et 24 al., 2016). This "hangover" effect is in line with the knowledge that FSH acts at the early 
1 spermatogenic stages and suggests that the stimulation required to obtain a sustained

2 improvement of the end product, i.e. the sperm, should cover more than only one spermatogenic 3 cycle.

$4 \quad$ Finally, the end point to evaluate FSH efficacy remains challenging. While pregnancy and live

5 birth rates are the strongest endpoints to assess efficacy of any infertility therapy, their strength is

6 weakened by a number of hidden biases. Indeed, pregnancy rate is the final result of sperm and

7 oocyte quality, combining the endogenous and exogenous variables interfering with gamete 8 production in both sexes. In the absence of a direct, pharmacodynamic marker of FSH action, the 9 evaluation of sperm production and quality is the only and most appropriate endpoint we have. Notably, the current available guidelines recommend against the treatment of male idiopathic infertility without a specific diagnostic workup (Barbonetti, et al., 2018, Colpi, et al., 2018) and underline the lack of evidence in favour of a generalized beneficial FSH effect on male.

\section{Responders and non-responders}

Overall, meta-analyses suggest FSH efficacy but heterogeneity of patient populations results in weak statistics, which will never improve unless we are able to recognize a priori "responders" and "non-responders". This concept was introduced in this field over twenty years ago (Foresta, et al., 1998) and has been repeatedly applied a posteriori to analyze the results of FSH treatment (Foresta, et al., 2005, Foresta, et al., 2002, Foresta, et al., 2000, Foresta, et al., 2009). It is now clear, also from our recent survey of clinical practice in Italy involving the largest number of men treated with FSH so far, that $30-50 \%$ of the patients respond to the current, empirical FSH regimens with an improvement of sperm count (Santi, et al., Submitted). De facto, this is a rather crude parameter of 23 FSH action, for which we still do not have any reliable pharmacodynamic marker. 
Foresta et al. (Foresta, et al., 2005, Foresta, et al., 2002, Foresta, et al., 2000, Foresta, et al.,

2 2009) proposed that patients with a spermatogenetic arrest are expected not to respond to FSH,

3 the action of which is exerted mainly at the spermatogonial level. This concept did not receive any 4 independent confirmation so far.

Assuming a dose-dependency of the response to $\mathrm{FSH}$, another explanation could lie in the

individual genetic background. It has been shown that common polymorphisms in the FSHB gene

7 promoter, influencing gene transcription and, thereby, FSH production, and in the FSHR gene,

8 influencing expression levels and signal transduction, can determine serum levels of FSH and, more

9 in general, the amount of FSH activity to which the testis is exposed (Simoni and Casarini, 2014, 10 Tuttelmann, et al., 2012). A pharmacogenetic approach to FSH treatment of male idiopathic 11 infertility has been tried with contrasting results (Ferlin, et al., 2011, Selice, et al., 2011, Simoni, et 12 al., 2016) and the correct approach is not established yet (Busch, et al., 2015, Schubert, et al., 2019). 13 It is reasonable to think that the genetic background, perhaps involving a wider spectrum of genes 14 than that explored so far, can influence response to FSH but the way is still long before the entire 15 picture is revealed. An a posteriori, comprehensive genetic analysis of responders and non16 responders could be useful to this purpose.

17 Whatever the explanation is (FSH regimen, spermatogenetic blockade, genetic background or 18 other), the impossibility to recognize a priori responders and non-responders derives essentially 19 from the intrinsic limitation of the instrument that we have to evaluate the infertile man, i.e. semen 20 analysis. This is a very "primitive" examination, full of drawbacks and not indicative at all of the 21 testicular phenotype, not even in case of azoospermia (Cito, et al., 2018). We need new instruments, 22 possibly non-invasive, to characterize better the testicular phenotype of infertile men and to dissect 23 the mess of "idiopathic infertility" into discrete subgroups characterized by common features at the 24 testicular level. Radically new approaches, e.g. determination of nanoscale components of biological 
1 samples (Ouyang and Han, 2019), comprehensive genetic analysis and markers (Cariati, et al., 2019,

2 Hotaling and Carrell, 2014), big data analysis by machine learning (Santi, et al., 2018), ultrastructural

3 in vivo imaging (Blazquez-Llorca, et al., 2015), are necessary to obtain some progress. Meanwhile,

4 we must do with what we have, and a paradigm change in pharmacologic FSH treatment of male

$5 \quad$ infertility should take place.

6

\section{A paradigm change is necessary}

Several lines of evidence support the concept that spermatogenesis can be boosted beyond the physiological level using larger FSH doses than those applied so far and for longer periods.

First of all, it seems that spermatogenesis does not run at its top. In the prepubertal human testis, FSH stimulates Sertoli cell proliferation, proliferation of A spermatogonia, cytoscheletal rearrangements (spermatogonia migration, tight junctions, etc..), increase in inhibin $B$ and testis volume (Dwyer, et al., 2013). Once the number of Sertoli cells is fixed, FSH effect can only be exerted on spermatogonial proliferation. This is suggested by several animal models of hemicastration, which is usually followed by a compensatory increase in volume of the remaining testis. This increase is supported by a rise in endogenous $\mathrm{FSH}$, driven by the decrease in inhibin $\mathrm{B}$, a marker of spermatogonial-Sertoli interaction, following the removal of one testis (Bercovici, et al., 1985, Brown, et al., 1990, Cunningham, et al., 1978, Johnson and Neaves, 1983, Ramaswamy, et al., 2000). The effect of hemicastration is evident also in humans, although the picture is tarnished by the usual presence of a tumor (Leydig or germ cell tumor) in the removed testis (Bercovici, et al., 1985). In the primate, the compensatory FSH effect on the remaining, adult testis is stimulation of proliferation of B spermatogonia (Ramaswamy, et al., 2000).

Other human models suggesting that FSH overstimulation can boost spermatogenesis are pituitary FSH-secreting adenomas, which are usually accompanied by quite large testicular volumes, 
1 decreasing after surgery even in the presence of normal LH and testosterone levels (Dahlqvist, et

2 al., 2010). Activating FSHR mutations demonstrate the ability of FSH to fully support

3 spermatogenesis in the absence of androgens (Casas-Gonzalez, et al., 2012, Gromoll, et al., 1996),

4 even in the murine model (Oduwole, et al., 2018). As described above, FSHB and FSHR inactivating

5 mutations in humans demonstrate that signal transduction pathways different from the canonical

6 cAMP are essential for full FSH action and can support such residual activity (Tranchant, et al., 2011).

7 This is an important concept, because today we know that the molecular action of FSH includes

8 several signal transduction pathways, engaged in specific time- and dose-dependent manner and

9 finely involved in the regulation of cell fate (proliferation vs. apoptosis) and metabolism (Casarini 10 and Crepieux, 2019). Any modern appraisal of FSH-dependent events must consider this complexity.

11 This might be, in principle, one molecular explanation why FSH in therapy is effective only in 12 "responders". These men could be those in whom a relatively low dose of extra FSH is sufficient to 13 stimulate the full spectrum of signal transduction.

14 We have been too cautious in attempting pharmacological FSH therapy for male idiopathic 15 infertility. The treatment regimens used so far were kind of "substitutive", with the classical 16 endocrinological approach used in hypogonadotropic hypogonadism. But men with idiopathic 17 infertility are not hypogonadal, they have their own FSH but reduced spermatogenesis: treating 18 them with a replacement dosage does not change essentially the situation and might be one reason 19 why the current regimens are ineffective in $50 \%$ of the cases. However, remarkably, $50 \%$ of men 20 respond in spite of the low dosage applied (Santi, et al., Submitted). This does not prove that FSH is 21 ineffective, although statistically it may be so. This rather suggests that half of the men did not 22 receive a pharmacological dose sufficiently high to challenge spermatogenesis over the baseline. 23 Men with idiopathic infertility should not be considered "functionally hypogonadal" any longer: they 
1 have a problem in spermatogenesis, which we do not understand (they are idiopathic), and need an

2 extra stimulus with a different approach, rather than a gonadotropin replacement.

3 Together with the results of the few clinical studies conducted so far, these are the reasons why

4 a paradigm change is necessary. We should adopt a more aggressive attitude and start trials based

5 on higher FSH dosages for longer times. Boosting spermatogenesis over the baseline should be

6 regarded as something alike controlled ovarian hyperstimulation, which, similarly, aims at obtaining

7 more oocytes than normal. It is time to develop pharmacological testicular hyperstimuation

8 protocols to be applied to men with idiopathic infertility and normal FSH levels.

9 51

\section{Is pharmacological testicular hyperstimulation expected to be risky?}

The clinical consequences of FSH hyperstimulation are quite different in males and in

females. In women an excess of FSH may result in ovarian hyperstimulation syndrome (OHSS), as demonstrated by FSH-secreting tumors (Caretto, et al., 2017, Galway, et al., 1990, Macchia, et al., 2012, Snyder, 1987, Valimaki, et al., 1999) and activating FSHR mutations (Lussiana, et al., 2008), in addition to the OHSS which can result from ART. In men, this does not occur: the expected consequence of pharmacological doses of FSH is, if any, stimulation of spermatogenesis and testis volume over the baseline, which is exactly what we want to achieve. No serious adverse events were ever reported as a consequence of FSH replacement treatment in males and FSH producing tumors have no other effect than increasing testis size. Extragonadal effects of FSH are a very much debated issue (Chrusciel, et al., 2019, Lizneva, et al., 2019) and, for the time being, should not be a concern. 21 The experimental evidence in humans demonstrates that FSH has no direct role in bone turnover or 22 other metabolic functions (Crawford, et al., 2017, Drake, et al., 2010, Uihlein, et al., 2014).

Would a pharmacological FSH stimulation result in FSHR downregulation and, thereby, loss of FSH effect? There is no evidence in vivo that this would occur. FSH hyperstimulation in women can 
1 result in OHSS, which would not happen if the receptor was downregulated. Actually, all endocrine

2 syndromes resulting from an excess of pituitary hormones, e.g. due to a pituitary tumor,

3 demonstrate that receptor down-regulation does not occur, or, if it occurs, is not sufficient to

4 reduce the effects of the pituitary hormone excess. The only G protein-coupled receptor down

5 regulation clinically known and exploited for therapeutic purposes is the GnRHR: superagonist

6 analogs of $\mathrm{GnRH}$ are able to downregulate the receptor (after a flareup phase) and this is useful to

7 shut down gonadotropin secretion. But the GnRHR is an exception. Rather than turning off signal

8 transduction, a supraphysiologic FSHR stimulation is expected to activate all signal transduction

9 pathways involved, including those entering in action after receptor internalization (Sayers and 10 Hanyaloglu, 2018), permitting the full spectrum of FSH action, which might be defective in some 11 cases of idiopathic infertility.

\section{Which gonadotropin for pharmacological testicular hyperstimulation?}

Historically, gonadotropins have been used already in the eighties in the attempt to

stimulate spermatogenesis in men with idiopathic infertility with negative results. The studies 16 conducted according to the golden design (prospective, double-blind, randomized, placebo17 controlled) failed to demonstrate a clinical effect in the overall population investigated (Table 1). 18 The lack of significant difference between placebo and verum group set every time a stop in further 19 research on this issue for long years. There are several reasons why these studies failed: treatment 20 protocol designed on analogy of the substitution treatment of hypogonadotropic hypogonadism 21 (albeit for a much shorter time); insufficient dosage and duration of therapy, type of gonadotropin 22 used, and, perhaps more importantly, impossibility of a priori patient stratification, i.e. 23 personalization of therapy, a concept now widely applied in other fields of medicine. In any case, 24 such studies clearly demonstrated that that sort of gonadotropin stimulation was overall ineffective, 
1 at the regimen used, to improve sperm parameters. Now that we know more about FSH action, 2 pharmacogenetics, dose-dependency of the effect, efficacy in some groups of patients, and possible 3 effect on pregnancy rate, both spontaneous and after ART, we need to try another approach. For the time being, the best option to test, in an appropriate prospective trial, the paradigm 5 change proposed here is FSH alone. It might be recombinant or urinary, since both have been used with substantially equal results (Cannarella, et al., 2019, Santi, et al., 2015). The only difference 7 between the existing FSH preparations is the route of administration (sc vs. im) which, given the required long duration of therapy, might pose a compliance problem (Cannarella, et al., 2019).

Not all existing FSH preparations are registered for use in the male. Highly purified urinary $10 \mathrm{FSH}$, follitropin alfa, follitropin beta and biosimilars are registered for male hypogonadotropic 11 hypogonadism and could be used already now and are indeed used in clinical practice in Italy (Santi, 12 et al., Submitted). A meaningful increase in dosage and duration would require 300 IU three times/week or 150 IU daily for four-six months to cover at least two spermatogenetic cycles, which 14 is a demanding schedule. This should be tested in a controlled clinical trial, which should, in addition, collect all information and be powered to stratify the patients a posteriori, e.g. sDF or genetic 16 background. This will be the only way to personalize pharmacological FSH treatment of male 17 idiopathic infertility. The feasibility of a placebo arm in such a long-lasting trial should be considered carefully. At least a no-treatment control arm must be included. Before such a trial is performed to

ultimately demonstrate if pharmacological FSH doses really improve male fertility potential and in which patients, no meaningful pharmacoeconomic projections can be made.

The newest molecules, follitropin delta, follitropin gamma and chorifollitropin have a more 22 favorable pharmacokinetics profile and would permit less injections. The ideal preparation should 23 allow one injection/month. While a very-long-acting FSH is not suited for use in ART, it would be 
1 ideal for treatment of male infertility/hypogonadism. New strategies are being attempted in this 2 respect (Zhang, et al., 2016) and should be further pursued.

A crucial point in performing a trial of high-dose FSH treatment of male infertility is the

4 collaboration of drug companies, which, unfortunately, are overtly uninterested. Those producing

5 follitropin alfa see no advantage in embarking in a costly trial because their patent expired and the 6 results could be exploited by any other company producing FSH. Follitropin delta and chorifollitropin

7 could represent ideal drugs, having a longer half-life, but the respective companies do not see the 8 business, partly because they do not believe that men would accept treatment, but there are other

9 reasons. Gonadotropin companies are de facto driving the clinical use of their products, limiting 10 their clientele to receptive doctors especially in ART centers, and do not intend to expand the 11 spectrum of possible users. It is not a matter of scientific evidence, since gonadotropin use in ART 12 is the least evidence-based treatment in medicine, it is a matter of marketing at large. It goes 13 without need of complex calculations that the amount of FSH required for one cycle of ovarian 14 stimulation $(2,000-5,000 \mathrm{IU})$ is much less than the amount which would be used in men 15 (approximately $10,000-30,000 \mathrm{IU}$ ). If FSH is really effective in improving semen quality and 16 pregnancy rate, gonadotropins sales would increase (at least two-six times) but the ART business 17 might decrease if spontaneous pregnancies occur, reducing the revenues of ART centers (Gleicher, 18 et al., 2019). However, ART centers could become interested in different business models, involving 19 male treatment. Here a mentality change is required, based also on accurate pharmacoeconomic 20 calculations and ad hoc business cases, which so far, were not considered attractive enough by 21 gonadotropin producing companies. In such a situation, the battle for trials to find the best 22 treatment regimen of male infertility is lost from the outset. 23 Is there any role for other gonadotropins, e.g. hCG, hMG or LH? Currently, one popular hMG 

1 hCG. Other preparations consist of a 1:1 mixture of urinary FSH and hCG (no LH), while a further,
2 recombinant hMG is in development by mixing recombinant FSH and recombinant hCG. Using hMG
3 instead of FSH would only jeopardize the results of future clinical trials, not permitting to dissect the
4 role of $\mathrm{FSH}$ alone and introducing another variable. A crucial problem is that, using $\mathrm{hMG}$, the dosage
5 of FSH cannot be increased without increasing LH activity as well, which means introducing the
6 possibility of a Leydig cell overstimulation and excessive testosterone production and
7 androgenization and suppression of endogenous gonadotropins. Therefore, future treatment
8 protocols/clinical trials cannot be based on hMG.

$9 \quad$ There are some data suggesting that Leydig cell function may be reduced in men with idiopathic 10 infertility, as indicated by the generally low (albeit still within the normal range) serum testosterone 11 levels in these men (Andersson, et al., 2004, Begum, et al., 2016). Would these patients benefit from 12 LH supplementation? The old studies using hCG (Knuth, et al., 1987) do not indicate this. However, 13 hCG is not the natural Leydig cell-stimulating hormone in the adult and shows pro-inflammatory 14 activity in the testis (Bergh, et al., 1996, Bergh, et al., 1993). Finally, we now know that hCG and LH 15 have different molecular actions and are biased ligands for the same receptor exerting different 16 functions (Casarini, et al., 2018). Therefore, should LH activity supplementation be required in some 17 men, recombinant LH should be tested. The short half-life of this hormone might be an obstacle, 18 although this should be investigated in a proper dose-finding, pharmacodynamic study in men. If $\mathrm{LH}$ 19 will become a useful asset in treatment of male infertility in the future, radically new biomolecules, 20 displaying the full spectrum of LH molecular activities, will need to be designed to allow more distant 21 administrations, as mentioned above for FSH. Several studies in animal models showed a partial 22 overlap between FSH and testosterone action on Sertoli cells (Oduwole, et al., 2018). The 23 pharmacological action of FSH alone could be insufficient to compensate a concomitant missing 
androgen action. The possible combined pharmacologic effect of FSH and LH on spermatogenesis

should be evaluated more in details by properly designed clinical trials.

\section{Conclusions: call for international action}

Couple infertility treatment remains the most gender-unfair therapy known. Infertile couples are not aware of this problem and the ART professionals have no interest in sensitizing public opinion on this topic. Infertility treatment is confined to the private sphere and insufficient, serious, public research is conducted in this field. Infertility in general is not perceived as a medical problem in an overpopulated world, and there are no dedicated programs by granting agencies. The care for the infertile male falls into the more general problem of men's health, a topic that starts now to gain some attention by the scientific community (De Jonge and Barratt, 2019, Ravitsky and Kimmins, 2019, WHO, 2018).

ART works well but it is an industry-driven, rapidly and steadily evolving technology, so that 14 we cannot estimate its long-term consequences. Every year more than 1 million ART cycles are 15 performed in the world and about 300,000 ART children are born (Kushnir, et al., 2017). There is 16 already some indication that boys conceived by ICSI for male infertility have reduced semen quality 17 compared to naturally conceived controls (Belva, et al., 2017). Apart from this, epigenetic effects 18 are more common in ART children and we do not have the full spectrum yet (Santi, et al., 2017). 19 Meanwhile, thanks to the introduction of novel inventions (e.g. single embryo transfer, blastocyst 20 culture, preimplantation genetic screening, time lapse, etc) and the enormous commercial interests 21 behind them, ART performance is decreasing and the main goal of the big, private owners of ART 22 clinics seems to be the revenue rather than clinical outcome. New technologies led to a rapid 23 evolution of reproduction toward a very profitable, sex-free practice (Gleicher, et al., 2019). Despite 24 ART is co-funded by public health services in several countries worldwide, in the vast majority of 
ART centers around the world it remains in private hands. Thus, in these countries, the treatment seems to be possible only for wealthy people: this is unjust and overtly against the WHO SDG target

\section{6 - gender equality/sexual and reproductive health (WHO, 2018).}

The Scientific Societies in Andrology, Endocrinology and Reproductive Medicine are urgently called to action in several directions. We should change our attitude towards gonadotropin treatment of the idiopathic infertile male by performing a really powerful, multicenter, phase 2 trial, radically changing the cautious/skeptical approach used so far, with the aim of defining novel, evidence-based, personalized therapeutic regimens. If drug companies are deaf to this call, we should make aware of the problem the Medicines Agencies (EMA, FDA, National Agencies): they cannot agree with the current, empirical way of approaching couple infertility and should stimulate companies to support innovative trials. If industry does not want to get involved in fully sponsored, registration studies, they should support investigator-started trials.

Meanwhile basic researchers should invent new, really long-acting gonadotropins for the treatment of male infertility. We should sensitize patients' and women' organization to the problem of male infertility: women should not accept anymore to be treated instead of their partner if a medical treatment of the male is available. Finally, interdisciplinary collaborations should promote industry-independent, pharmacoeconomic studies, to show the real impact of male infertility care on the socio-economic and health system.

\section{Acknowledgements}

MS is a LE STUDIUM RESEARCH FELLOW, Loire Valley Institute for Advanced Studies, Orléans \& Tours, France-INRA-Center Val de Loire, 37380 Nouzilly, France, receiving funding from the European Union's Horizon 2020 research and innovation programme under the Marie SkłodowskaCurie grant agreement No. 665790 . 


\section{References}

2 Abel MH, Baker PJ, Charlton HM, Monteiro A, Verhoeven G, De Gendt K, Guillou F, O'Shaughnessy

3 PJ. Spermatogenesis and sertoli cell activity in mice lacking sertoli cell receptors for follicle-

4 stimulating hormone and androgen. Endocrinology. 2008;149:3279-85.

5 Abel MH, Wootton AN, Wilkins V, Huhtaniemi I, Knight PG, Charlton HM. The effect of a null

6 mutation in the follicle-stimulating hormone receptor gene on mouse reproduction.

7 Endocrinology. 2000;141:1795-803.

8 Allan CM, Garcia A, Spaliviero J, Zhang FP, Jimenez M, Huhtaniemi I, Handelsman DJ. Complete

9 Sertoli cell proliferation induced by follicle-stimulating hormone (FSH) independently of luteinizing 10 hormone activity: evidence from genetic models of isolated FSH action. Endocrinology.

$112004 ; 145: 1587-93$.

12 Andersson AM, Jorgensen N, Frydelund-Larsen L, Rajpert-De Meyts E, Skakkebaek NE. Impaired 13 Leydig cell function in infertile men: a study of 357 idiopathic infertile men and 318 proven fertile 14 controls. J Clin Endocrinol Metab. 2004;89:3161-7.

15 Ashkenazi J, Bar-Hava I, Farhi J, Levy T, Feldberg D, Orvieto R, Ben-Rafael Z. The role of purified 16 follicle stimulating hormone therapy in the male partner before intracytoplasmic sperm injection.

17 Fertil Steril. 1999;72:670-3.

18 Attia AM, Abou-Setta AM, Al-Inany HG. Gonadotrophins for idiopathic male factor subfertility.

19 Cochrane Database Syst Rev. 2013:CD005071.

20 Attia AM, Al-Inany HG, Farquhar C, Proctor M. Gonadotrophins for idiopathic male factor

21 subfertility. Cochrane Database Syst Rev. 2007:Cd005071.

22 Baccetti B, Piomboni P, Bruni E, Capitani S, Gambera L, Moretti E, Sterzik K, Strehler E. Effect of 23 follicle-stimulating hormone on sperm quality and pregnancy rate. Asian J Androl. 2004;6:133-7. 

4

1 Barbonetti A, Calogero AE, Balercia G, Garolla A, Krausz C, La Vignera S, Lombardo F, Jannini EA,

2 Maggi M, Lenzi A, Foresta C, Ferlin A. The use of follicle stimulating hormone (FSH) for the

3 treatment of the infertile man: position statement from the Italian Society of Andrology and

4 Sexual Medicine (SIAMS). J Endocrinol Invest. 2018;41:1107-1122.

5 Bartoov B, Eltes F, Lunenfeld E, Har-Even D, Lederman H, Lunenfeld B. Sperm quality of subfertile

6 males before and after treatment with human follicle-stimulating hormone. Fertil Steril.

$7 \quad$ 1994;61:727-34.

8 Begum N, Anwary SA, Alfazzaman M, Mahzabin Z, Nahar K, Rahman MM, Mostafa MA. Role of

9 Serum Follicle Stimulating Hormone, Luteinizing Hormone, Testosterone and Prolactin Levels in

10 Azoospermic Male Partner of Subfertile Couple. Mymensingh Med J. 2016;25:303-7.

11 Belva F, Roelants M, De Schepper J, Van Steirteghem A, Tournaye H, Bonduelle M. Reproductive

12 hormones of ICSI-conceived young adult men: the first results. Hum Reprod. 2017;32:439-446.

13 Ben-Rafael Z, Farhi J, Feldberg D, Bartoov B, Kovo M, Eltes F, Ashkenazi J. Follicle-stimulating

14 hormone treatment for men with idiopathic oligoteratoasthenozoospermia before in vitro

15 fertilization: the impact on sperm microstructure and fertilization potential. Fertil Steril.

$16 \quad 2000 ; 73: 24-30$.

17 Bercovici JP, Nahoul K, Ducasse M, Tater D, Kerlan V, Scholler R. Leydig cell tumor with 18 gynecomastia: further studies--the recovery after unilateral orchidectomy. J Clin Endocrinol 19 Metab. 1985;61:957-62.

20 Bergh A, Damber JE, Hjertkvist M. Human chorionic gonadotrophin-induced testicular

21 inflammation may be related to increased sensitivity to interleukin-1. Int J Androl. 1996;19:229-36.

22 Bergh A, Damber JE, van Rooijen N. The human chorionic gonadotrophin-induced inflammation23 like response is enhanced in macrophage-depleted rat testes. J Endocrinol. 1993;136:415-20. 
1 Blazquez-Llorca L, Hummel E, Zimmerman H, Zou C, Burgold S, Rietdorf J, Herms J. Correlation of

2 two-photon in vivo imaging and FIB/SEM microscopy. J Microsc. 2015;259:129-136.

3 Brown JL, Schoenemann HM, Chakraborty PK, Stuart LD, Dahl KD. Increased bioactivity of serum

4 follicle-stimulating hormone, but not luteinizing hormone, following hemicastration in ram lambs.

$5 \quad$ Biol Reprod. 1990;43:548-53.

6 Busch AS, Kliesch S, Tuttelmann F, Gromoll J. FSHB -211G >T stratification for follicle-stimulating

7 hormone treatment of male infertility patients: making the case for a pharmacogenetic approach

8 in genetic functional secondary hypogonadism. Andrology. 2015;3:1050-3.

9 Cannarella R, La Vignera S, Condorelli RA, Mongioi LM, Calogero AE. FSH dosage effect on

10 conventional sperm parameters: a meta-analysis of randomized controlled studies. Asian J Androl.

112019.

12 Caretto A, Lanzi R, Piani C, Molgora M, Mortini P, Losa M. Ovarian hyperstimulation syndrome due 13 to follicle-stimulating hormone-secreting pituitary adenomas. Pituitary. 2017;20:553-560.

14 Cariati F, D'Argenio V, Tomaiuolo R. The evolving role of genetic tests in reproductive medicine. J

15 Transl Med. 2019;17:267.

16 Caroppo E, Niederberger C, Vizziello GM, D'Amato G. Recombinant human follicle-stimulating

17 hormone as a pretreatment for idiopathic oligoasthenoteratozoospermic patients undergoing

18 intracytoplasmic sperm injection. Fertil Steril. 2003;80:1398-403.

19 Casarini L, Crepieux P. Molecular Mechanisms of Action of FSH. Front Endocrinol (Lausanne).

$20 \quad 2019 ; 10: 305$.

21 Casarini L, Santi D, Brigante G, Simoni M. Two Hormones for One Receptor: Evolution,

22 Biochemistry, Actions, and Pathophysiology of LH and hCG. Endocr Rev. 2018;39:549-592.

23 Casas-Gonzalez P, Scaglia HE, Perez-Solis MA, Durand G, Scaglia J, Zarinan T, Dias JA, Reiter E,

24 Ulloa-Aguirre A. Normal testicular function without detectable follicle-stimulating hormone. A 
1 novel mutation in the follicle-stimulating hormone receptor gene leading to apparent constitutive

2 activity and impaired agonist-induced desensitization and internalization. Mol Cell Endocrinol.

$3 \quad 2012 ; 364: 71-82$.

4 Cheng CY, Mruk DD. Cell junction dynamics in the testis: Sertoli-germ cell interactions and male

5 contraceptive development. Physiol Rev. 2002;82:825-74.

6 Chrusciel M, Ponikwicka-Tyszko D, Wolczynski S, Huhtaniemi I, Rahman NA. Extragonadal FSHR

7 Expression and Function-Is It Real? Front Endocrinol (Lausanne). 2019;10:32.

8 Cito G, Coccia ME, Picone R, Nesi G, Cocci A, Dabizzi S, Garaffa G, Fucci R, Falcone P, Bertocci F,

9 Santi R, Criscuoli L, Serni S, Carini M, Natali A. Novel method of histopathological analysis after 10 testicular sperm extraction in patients with nonobstructive and obstructive azoospermia. Clin Exp 11 Reprod Med. 2018;45:170-176.

12 Colacurci N, Monti MG, Fornaro F, Izzo G, Izzo P, Trotta C, Mele D, De Franciscis P. Recombinant 13 human FSH reduces sperm DNA fragmentation in men with idiopathic 14 oligoasthenoteratozoospermia. J Androl. 2012;33:588-93.

15 Colpi GM, Francavilla S, Haidl G, Link K, Behre HM, Goulis DG, Krausz C, Giwercman A. European 16 Academy of Andrology guideline Management of oligo-astheno-teratozoospermia. Andrology. $17 \quad 2018 ; 6: 513-524$.

18 Crawford ED, Schally AV, Pinthus JH, Block NL, Rick FG, Garnick MB, Eckel RH, Keane TE, Shore ND, 19 Dahdal DN, Beveridge TJR, Marshall DC. The potential role of follicle-stimulating hormone in the 20 cardiovascular, metabolic, skeletal, and cognitive effects associated with androgen deprivation 21 therapy. Urol Oncol. 2017;35:183-191.

22 Cunningham GR, Tindall DJ, Huckins C, Means AR. Mechanisms for the testicular hypertrophy 23 which follows hemicastration. Endocrinology. 1978;102:16-23. 
1 Dahlqvist $\mathrm{P}$, Koskinen LO, Brannstrom T, Hagg E. Testicular enlargement in a patient with a FSH-

2 secreting pituitary adenoma. Endocrine. 2010;37:289-93.

3 De Jonge C, Barratt CLR. The present crisis in male reproductive health: an urgent need for a

4 political, social, and research roadmap. Andrology. 2019.

5 Ding YM, Zhang XJ, Li JP, Chen SS, Zhang RT, Tan WL, Shi XJ. Treatment of idiopathic

6 oligozoospermia with recombinant human follicle-stimulating hormone: a prospective,

7 randomized, double-blind, placebo-controlled clinical study in Chinese population. Clin Endocrinol

8 (Oxf). 2015;83:866-71.

9 Drake MT, McCready LK, Hoey KA, Atkinson EJ, Khosla S. Effects of suppression of follicle-

10 stimulating hormone secretion on bone resorption markers in postmenopausal women. J Clin

11 Endocrinol Metab. 2010;95:5063-8.

12 Dwyer AA, Sykiotis GP, Hayes FJ, Boepple PA, Lee H, Loughlin KR, Dym M, Sluss PM, Crowley WF, 13 Jr., Pitteloud N. Trial of recombinant follicle-stimulating hormone pretreatment for GnRH-induced

14 fertility in patients with congenital hypogonadotropic hypogonadism. J Clin Endocrinol Metab.

15 2013;98:E1790-5.

16 Ferlin A, Vinanzi C, Selice R, Garolla A, Frigo AC, Foresta C. Toward a pharmacogenetic approach to 17 male infertility: polymorphism of follicle-stimulating hormone beta-subunit promoter. Fertil Steril. $18 \quad 2011 ; 96: 1344-1349$ e2.

19 Foresta C, Bettella A, Ferlin A, Garolla A, Rossato M. Evidence for a stimulatory role of follicle20 stimulating hormone on the spermatogonial population in adult males. Fertil Steril. 1998;69:6362142.

22 Foresta C, Bettella A, Garolla A, Ambrosini G, Ferlin A. Treatment of male idiopathic infertility with 23 recombinant human follicle-stimulating hormone: a prospective, controlled, randomized clinical 24 study. Fertil Steril. 2005;84:654-61. 
1 Foresta C, Bettella A, Merico M, Garolla A, Ferlin A, Rossato M. Use of recombinant human follicle-

2 stimulating hormone in the treatment of male factor infertility. Fertil Steril. 2002;77:238-44.

3 Foresta C, Bettella A, Merico M, Garolla A, Plebani M, Ferlin A, Rossato M. FSH in the treatment of 4 oligozoospermia. Mol Cell Endocrinol. 2000;161:89-97.

5 Foresta C, Selice R, Ferlin A, Garolla A. Recombinant FSH in the treatment of oligozoospermia.

6 Expert Opin Biol Ther. 2009;9:659-66.

7 Foresta C, Selice R, Moretti A, Pati MA, Carraro M, Engl B, Garolla A. Gonadotropin administration

8 after gonadotropin-releasing-hormone agonist: a therapeutic option in severe testiculopathies.

$9 \quad$ Fertil Steril. 2009;92:1326-32.

10 Galway AB, Hsueh AJ, Keene JL, Yamoto M, Fauser BC, Boime I. In vitro and in vivo bioactivity of 11 recombinant human follicle-stimulating hormone and partially deglycosylated variants secreted by 12 transfected eukaryotic cell lines. Endocrinology. 1990;127:93-100.

13 Gleicher N, Kushnir VA, Barad DH. Worldwide decline of IVF birth rates and its probable causes. 14 Hum Reprod Open. 2019;2019:hoz017.

15 Gromoll J, Simoni M, Nieschlag E. An activating mutation of the follicle-stimulating hormone 16 receptor autonomously sustains spermatogenesis in a hypophysectomized man. J Clin Endocrinol 17 Metab. 1996;81:1367-70.

18 Hotaling J, Carrell DT. Clinical genetic testing for male factor infertility: current applications and 19 future directions. Andrology. 2014;2:339-50.

20 Huhtaniemi IT, Yamamoto M, Ranta T, Jalkanen J, Jaffe RB. Follicle-stimulating hormone receptors 21 appear earlier in the primate fetal testis than in the ovary. J Clin Endocrinol Metab. 1987;65:1210224

23 Jan SZ, Hamer G, Repping S, de Rooij DG, van Pelt AM, Vormer TL. Molecular control of rodent 24 spermatogenesis. Biochim Biophys Acta. 2012;1822:1838-50. 
1 Johnson L, Neaves WB. Enhanced daily sperm production in the remaining testis of aged rats

2 following hemicastration. J Androl. 1983;4:162-6.

3 Kamischke A, Behre HM, Bergmann M, Simoni M, Schafer T, Nieschlag E. Recombinant human

4 follicle stimulating hormone for treatment of male idiopathic infertility: a randomized, double-

5 blind, placebo-controlled, clinical trial. Hum Reprod. 1998;13:596-603.

6 Kangasniemi M, Kaipia A, Toppari J, Perheentupa A, Huhtaniemi I, Parvinen M. Cellular regulation

7 of follicle-stimulating hormone (FSH) binding in rat seminiferous tubules. J Androl. 1990;11:336-

843.

9 Knuth UA, Honigl W, Bals-Pratsch M, Schleicher G, Nieschlag E. Treatment of severe oligospermia 10 with human chorionic gonadotropin/human menopausal gonadotropin: a placebo-controlled, 11 double blind trial. J Clin Endocrinol Metab. 1987;65:1081-7.

12 Kumar TR, Wang Y, Lu N, Matzuk MM. Follicle stimulating hormone is required for ovarian follicle 13 maturation but not male fertility. Nat Genet. 1997;15:201-204.

14 Kushnir VA, Barad DH, Albertini DF, Darmon SK, Gleicher N. Systematic review of worldwide trends 15 in assisted reproductive technology 2004-2013. Reprod Biol Endocrinol. 2017;15:6.

16 Lizneva D, Rahimova A, Kim SM, Atabiekov I, Javaid S, Alamoush B, Taneja C, Khan A, Sun L, Azziz R, 17 Yuen T, Zaidi M. FSH Beyond Fertility. Front Endocrinol (Lausanne). 2019;10:136.

18 Lussiana C, Guani B, Mari C, Restagno G, Massobrio M, Revelli A. Mutations and polymorphisms of 19 the FSH receptor (FSHR) gene: clinical implications in female fecundity and molecular biology of 20 FSHR protein and gene. Obstet Gynecol Surv. 2008;63:785-95.

21 Macchia E, Simoncini T, Raffaelli V, Lombardi M, lannelli A, Martino E. A functioning FSH-secreting 22 pituitary macroadenoma causing an ovarian hyperstimulation syndrome with multiple cysts 23 resected and relapsed after leuprolide in a reproductive-aged woman. Gynecol Endocrinol. $24 \quad 2012 ; 28: 56-9$. 

4

1 Matorras R, Perez C, Corcostegui B, Pijoan Jl, Ramon O, Delgado P, Rodriguez-Escudero FJ.

2 Treatment of the male with follicle-stimulating hormone in intrauterine insemination with

3 husband's spermatozoa: a randomized study. Hum Reprod. 1997;12:24-8.

4 Oduwole OO, Peltoketo H, Huhtaniemi IT. Role of Follicle-Stimulating Hormone in

5 Spermatogenesis. Front Endocrinol (Lausanne). 2018;9:763.

6 Oduwole OO, Peltoketo H, Poliandri A, Vengadabady L, Chrusciel M, Doroszko M, Samanta L,

7 Owen L, Keevil B, Rahman NA, Huhtaniemi IT. Constitutively active follicle-stimulating hormone

8 receptor enables androgen-independent spermatogenesis. J Clin Invest. 2018;128:1787-1792.

9 Ouyang W, Han J. Universal amplification-free molecular diagnostics by billion-fold hierarchical 10 nanofluidic concentration. Proc Natl Acad Sci U S A. 2019;116:16240-16249.

11 Paradisi R, Busacchi P, Seracchioli R, Porcu E, Venturoli S. Effects of high doses of recombinant 12 human follicle-stimulating hormone in the treatment of male factor infertility: results of a pilot 13 study. Fertil Steril. 2006;86:728-31.

14 Ramaswamy S, Marshall GR, McNeilly AS, Plant TM. Dynamics of the follicle-stimulating hormone 15 (FSH)-inhibin B feedback loop and its role in regulating spermatogenesis in the adult male rhesus 16 monkey (Macaca mulatta) as revealed by unilateral orchidectomy. Endocrinology. 2000;141:18-27. 17 Ravitsky $\mathrm{V}$, Kimmins $\mathrm{S}$. The forgotten men: rising rates of male infertility urgently require new 18 approaches for its prevention, diagnosis and treatment. Biol Reprod. 2019.

19 Roth MY, Lin K, Amory JK, Matsumoto AM, Anawalt BD, Snyder CN, Kalhorn TF, Bremner WJ, Page 20 ST. Serum LH correlates highly with intratesticular steroid levels in normal men. J Androl.

$21 \quad 2010 ; 31: 138-45$.

22 Ruwanpura SM, McLachlan RI, Meachem SJ. Hormonal regulation of male germ cell development. 23 J Endocrinol. 2010;205:117-31. 
1 Santi D, De Vincentis S, Alfano P, Allegra A, Balercia G, Calogero A, Cargnelutti F, Coccia ME, Dal

2 Lago A, De Angelis C, lannantuoni N, Lombardo F, Mazzella M, Pallotti F, Pivonello R, Rago R,

3 Rampini M, Salvio G, Simoni M. Use and effects of follicle-stimulating hormone (FSH) for idiopathic

4 male infertility in Italy: results from a multicentre, observational, cohort, open registry, real life,

5 clinical study Submitted.

6 Santi D, De Vincentis S, Magnani E, Spaggiari G. Impairment of sperm DNA methylation in male

7 infertility: a meta-analytic study. Andrology. 2017;5:695-703.

8 Santi D, Granata AR, Simoni M. Follicle-stimulating hormone treatment of male idiopathic

9 infertility improves pregnancy rate: a meta-analysis. Endocr Connect. 2015.

10 Santi D, Magnani E, Michelangeli M, Grassi R, Vecchi B, Pedroni G, Roli L, De Santis MC, Baraldi E, 11 Setti M, Trenti T, Simoni M. Seasonal variation of semen parameters correlates with

12 environmental temperature and air pollution: A big data analysis over 6 years. Environ Pollut.

$132018 ; 235: 806-813$.

14 Sayers N, Hanyaloglu AC. Intracellular Follicle-Stimulating Hormone Receptor Trafficking and 15 Signaling. Front Endocrinol (Lausanne). 2018;9:653.

16 Schubert M, Perez Lanuza L, Gromoll J. Pharmacogenetics of FSH Action in the Male. Front 17 Endocrinol (Lausanne). 2019;10:47.

18 Selice R, Garolla A, Pengo M, Caretta N, Ferlin A, Foresta C. The response to FSH treatment in 19 oligozoospermic men depends on FSH receptor gene polymorphisms. Int J Androl. 2011;34:3062012.

21 Sharpe RM, McKinnell C, Kivlin C, Fisher JS. Proliferation and functional maturation of Sertoli cells, 22 and their relevance to disorders of testis function in adulthood. Reproduction. 2003;125:769-84. 23 Simoni M, Casarini L. Mechanisms in endocrinology: Genetics of FSH action: a 2014-and-beyond 24 view. Eur J Endocrinol. 2014;170:R91-107. 


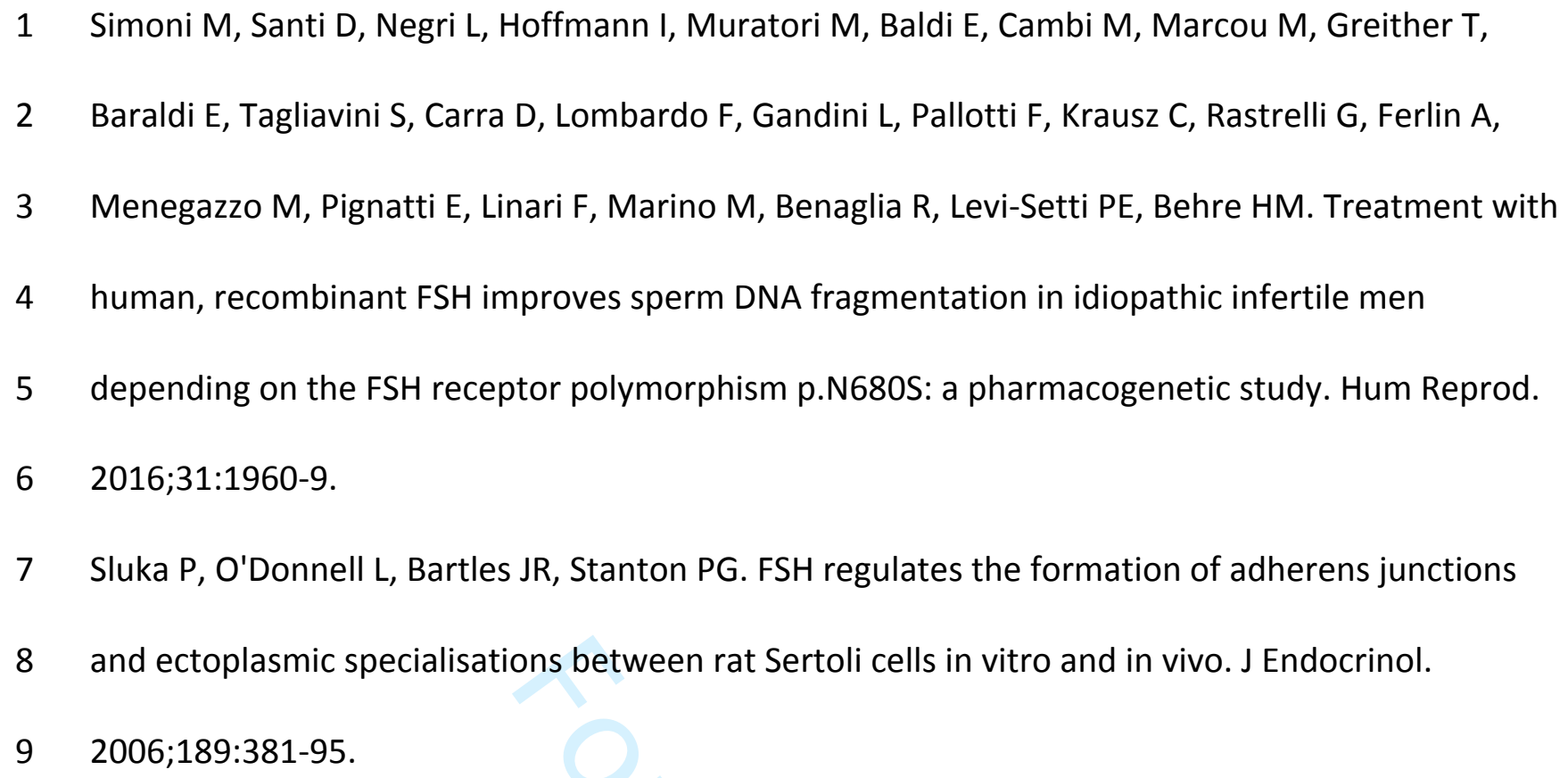


1 Valimaki MJ, Tiitinen A, Alfthan H, Paetau A, Poranen A, Sane T, Stenman UH. Ovarian

2 hyperstimulation caused by gonadotroph adenoma secreting follicle-stimulating hormone in 28-

3 year-old woman. J Clin Endocrinol Metab. 1999;84:4204-8.

4 WHO WHO. Strategy on the health and well-being of men in the

5 WHO European Region. Rome: WORLD HEALTH ORGANIZATION REGIONAL OFFICE FOR EUROPE, 62018.

7 Zhang YL, Guo KP, Ji SY, Liu XM, Wang P, Wu J, Gao L, Jiang TQ, Xu T, Fan HY. Development and

8 characterization of a novel long-acting recombinant follicle stimulating hormone agonist by fusing

9 Fc to an FSH-beta subunit. Hum Reprod. 2016;31:169-82.

10 Zheng J, Mao J, Cui M, Liu Z, Wang X, Xiong S, Nie M, Wu X. Novel FSHbeta mutation in a male 11 patient with isolated FSH deficiency and infertility. Eur J Med Genet. 2017;60:335-339.

12 Zimmermann C, Stevant I, Borel C, Conne B, Pitetti JL, Calvel P, Kaessmann H, Jegou B, Chalmel F, 13 Nef S. Research resource: the dynamic transcriptional profile of sertoli cells during the progression 14 of spermatogenesis. Mol Endocrinol. 2015;29:627-42. 
1 Table 1. FSH regimen used in clinical trials available in the literature.

\begin{tabular}{|c|c|c|c|c|}
\hline Author & Study design & $\begin{array}{l}\text { Number of } \\
\text { patients }\end{array}$ & $\begin{array}{l}\text { FSH } \\
\text { preparations }\end{array}$ & FSH scheme \\
\hline $\begin{array}{l}\text { (Ashkenazi, et } \\
\text { al., 1999) }\end{array}$ & Observational & $39 / 39$ & $\begin{array}{l}\text { Urinary-derived } \\
\text { FSH }\end{array}$ & 75 IU daily \\
\hline $\begin{array}{l}\text { (Baccetti, et } \\
\text { al., 2004) }\end{array}$ & RCT & $24 / 20$ & $\begin{array}{l}\text { Urinary-derived } \\
\text { FSH }\end{array}$ & 150 IU daily \\
\hline $\begin{array}{l}\text { (Bartoov, et al., } \\
\text { 1994) }\end{array}$ & Observational & $31 / 101$ & $\begin{array}{l}\text { Urinary-derived } \\
\text { FSH }\end{array}$ & 75 IU daily \\
\hline $\begin{array}{l}\text { (Ben-Rafael, et } \\
\text { al., 2000) }\end{array}$ & RCT & $20 / 20$ & $\begin{array}{l}\text { Urinary-derived } \\
\text { FSH }\end{array}$ & 75-150 IU daily \\
\hline $\begin{array}{l}\text { (Caroppo, et } \\
\text { al., 2003) }\end{array}$ & Observational & $23 / 23$ & $\begin{array}{l}\text { Recombinant } \\
\text { FSH }\end{array}$ & 150 IU on alternate days \\
\hline $\begin{array}{l}\text { (Colacurci, et } \\
\text { al., 2012) }\end{array}$ & RCT & $65 / 63$ & $\begin{array}{l}\text { Recombinant } \\
\text { FSH }\end{array}$ & 100 IU on alternate days \\
\hline $\begin{array}{l}\text { (Ding, et al., } \\
2015)\end{array}$ & RCT & $272 / 82$ & $\begin{array}{l}\text { Urinary-derived } \\
\text { FSH }\end{array}$ & $\begin{array}{l}50-100-200-300 \text { IU on } \\
\text { alternate days }\end{array}$ \\
\hline $\begin{array}{l}\text { (Foresta, et al., } \\
2000)\end{array}$ & Observational & $77 / 20$ & $\begin{array}{l}\text { Urinary-derived } \\
\text { FSH }\end{array}$ & 75 IU on alternate days \\
\hline $\begin{array}{l}\text { (Foresta, et al., } \\
2002)\end{array}$ & RCT & $30 / 15$ & $\begin{array}{l}\text { Recombinant } \\
\text { FSH }\end{array}$ & $\begin{array}{l}50-100 \text { IU on alternate } \\
\text { days }\end{array}$ \\
\hline $\begin{array}{l}\text { (Foresta, et al., } \\
2005)\end{array}$ & $\mathrm{RCT}$ & $62 / 50$ & $\begin{array}{l}\text { Recombinant } \\
\text { FSH }\end{array}$ & 100 IU on alternate days \\
\hline
\end{tabular}




\begin{tabular}{|c|c|c|c|c|}
\hline $\begin{array}{l}\text { (Foresta, et al., } \\
2009)\end{array}$ & $\mathrm{RCT}$ & $57 / 62$ & $\begin{array}{l}\text { Recombinant } \\
\text { FSH }\end{array}$ & 150 IU on alternate days \\
\hline $\begin{array}{l}\text { (Kamischke, et } \\
\text { al., 1998) }\end{array}$ & $\mathrm{RCT}$ & $34 / 33$ & $\begin{array}{l}\text { Recombinant } \\
\text { FSH }\end{array}$ & 150 IU daily \\
\hline $\begin{array}{l}\text { (Knuth, et al., } \\
1987)\end{array}$ & RCT & $19 / 20$ & hMG and hCG & $\begin{array}{l}75 \mathrm{IU} \text { and } 2500 \mathrm{IU} \text { daily, } \\
\text { respectively }\end{array}$ \\
\hline $\begin{array}{l}\text { (Matorras, et } \\
\text { al., 1997) }\end{array}$ & $\mathrm{RCT}$ & $58 / 78$ & $\begin{array}{l}\text { Urinary-derived } \\
\text { FSH }\end{array}$ & 150 IU on alternate days \\
\hline $\begin{array}{l}\text { (Paradisi, et al., } \\
2006)\end{array}$ & $\mathrm{RCT}$ & $15 / 15$ & $\begin{array}{l}\text { Recombinant } \\
\text { FSH }\end{array}$ & 300 IU on alternate days \\
\hline $\begin{array}{l}\text { (Selice, et al., } \\
\text { 2011) }\end{array}$ & RCT & $70 / 35$ & $\begin{array}{l}\text { Recombinant } \\
\text { FSH }\end{array}$ & 150 IU on alternate days \\
\hline $\begin{array}{l}\text { (Simoni, et al., } \\
2016)\end{array}$ & Non-RCT & $38 / 28$ & $\begin{array}{l}\text { Recombinant } \\
\text { FSH }\end{array}$ & 150 IU on alternate days \\
\hline
\end{tabular}

1 [Footnote to Table 1]: FSH: follicle-stimulating hormone; hCG: human chorionic gonadotropin; $h M G$ :

2 human menopausal gonadotropin; RCT: randomized clinical trial. 
1 Figure 1. Spermatogenesis representation, showing the role of FSH and testosterone.

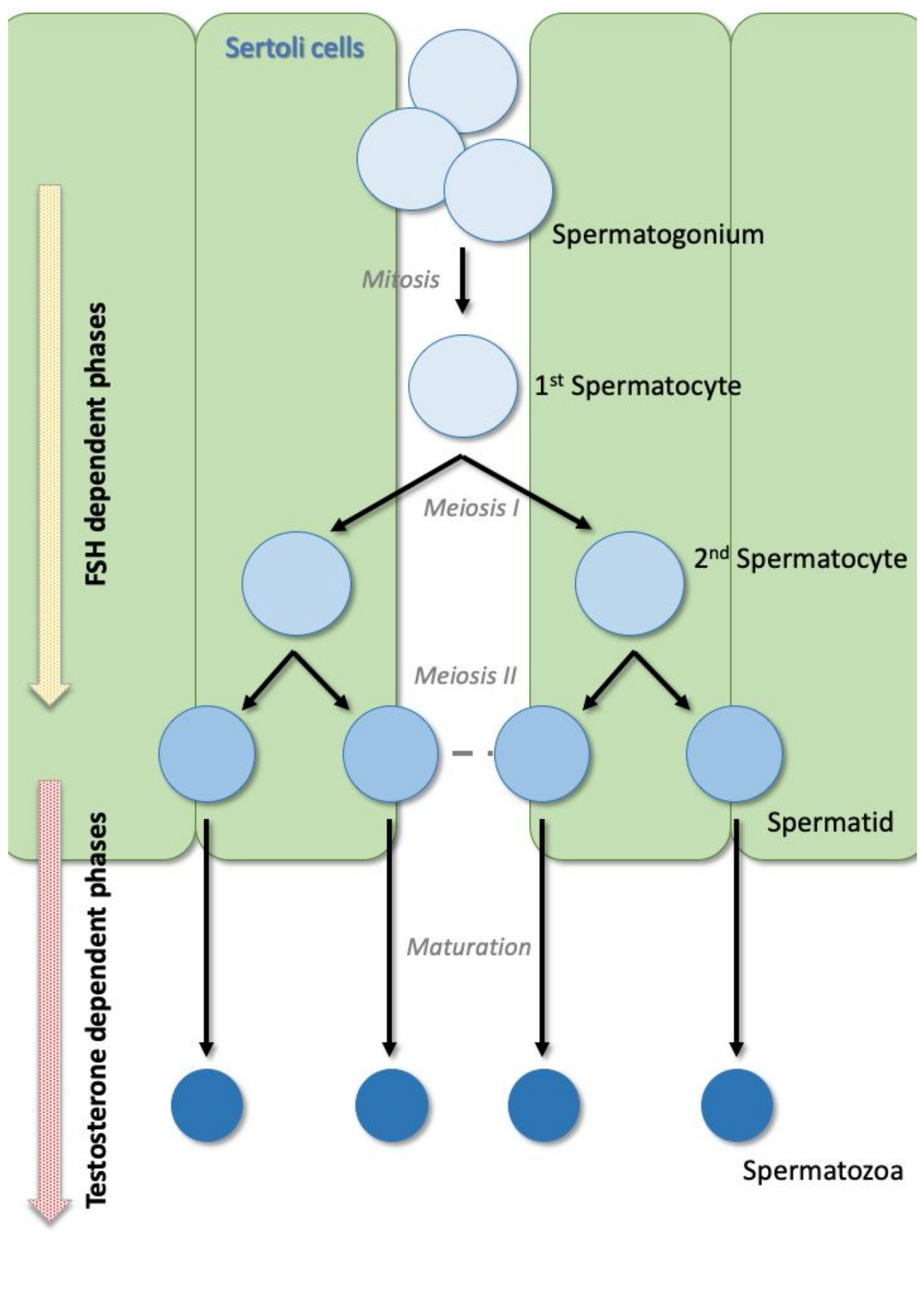




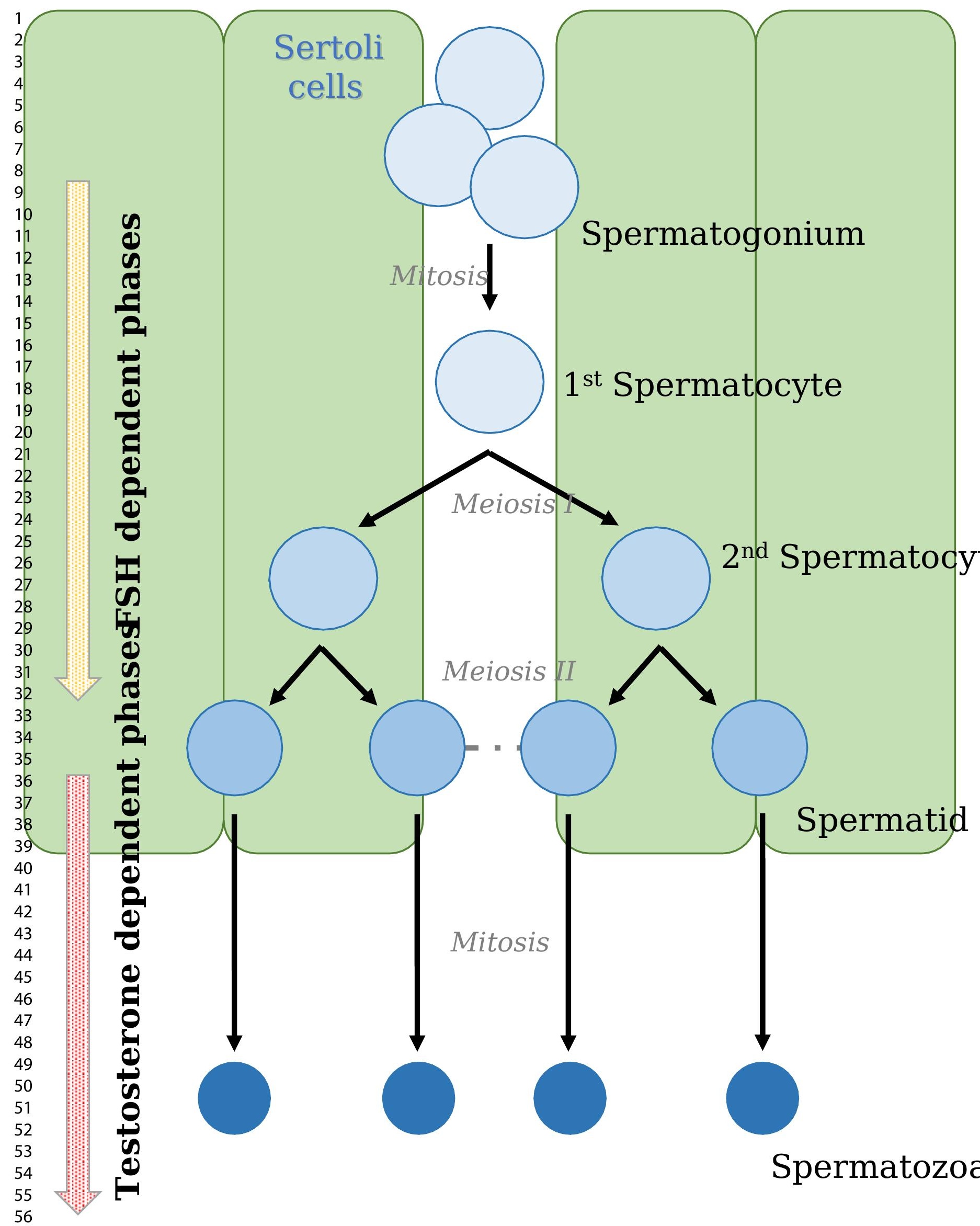

